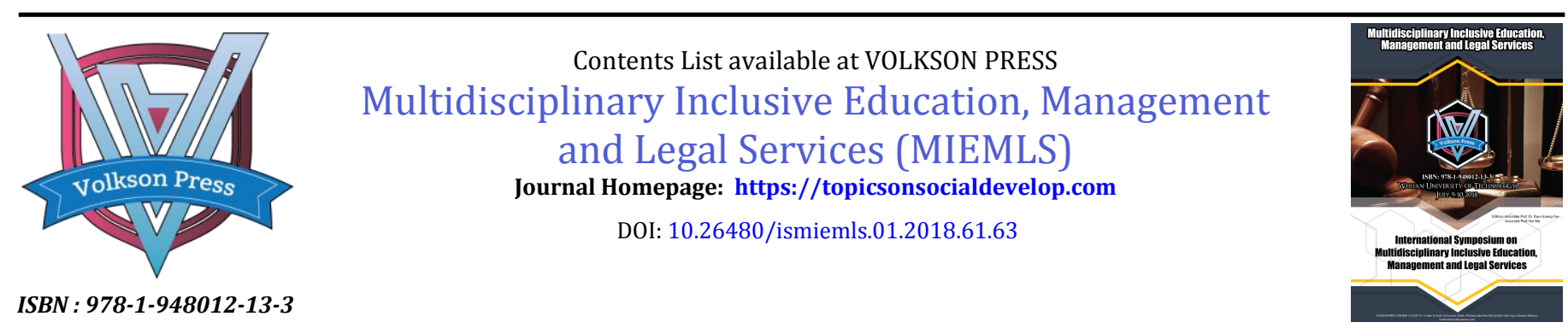

\title{
RESEARCH ON OMNI-CHANNEL BUSINESS MODEL OF RETAIL ENTERPRISE
}

\author{
Li Aohan' ${ }^{1}$, Zhou Min ${ }^{2}$ \\ ${ }^{1}$ Department of Business Management, Wuhan Business University, Wuhan City, China \\ ${ }^{2}$ Hubei Wuhan Tobacco Company Cigarette Logistics Distribution Center, Wuhan City, China
}

This is an open access article distributed under the Creative Commons Attribution License, which permits unrestricted use, distribution, and reproduction in any medium, provided the original work is properly cited.

\section{ARTICLE DETAILS}

\section{Article History:}

Received 26 June 2018 Accepted 2 July 2018 Available online 1 August 2018

\section{ABSTRACT}

With the development of the Internet and big data, a large number of retail enterprises transform to omni-channel retailers. This paper describes the omni-channel business model from the nine basic elements including "Customer Segments, Value Propositions, Channels, Customer Relationships, Revenue Streams, Key Resources, Key Activities, Key Partnerships and Cost Structure". On this basis, it explores the content of omni-channel business model innovation which includes three respects, industry state innovation, marketing innovation and technological innovation.

\section{KEYWORDS}

Omni-channel, Business model, Innovation.

\section{INTRODUCTION}

The development of the Internet and big data has eliminated the information asymmetry. Traditional retailers face the impact of cost and sales volume and e-commerce enterprises suffer from fierce and disorderly competition. Large traditional retailers such as Wal-mart and Suning have scaled back their physical stores and developed online retail businesses. E-commerce enterprises such as Alibaba and JD.com attempt to run offline businesses. The emerging trading channel and communication mode drive the consumer diversion and push the retail industry into the omni-channel era.

The retail industry has made many practical explorations in the omnichannel business model. On the basis of preserving the industry state of hypermarket, large retail enterprises have tried miniature state of retail trading and online sales platform. Wal-mart operates the online business very early, expands the channels in recent years and focus on multiple industry states, accelerates online and offline integration and provides whole time integrated shopping experience through the combination of offline physical stores and online business. Carrefour operates hypermarkets and a new industry state which is convenience store named as "carrefour Easy", meanwhile operates online stores to make sure customers can shop online and take delivery of goods offline. China Resources Vanguard develops the offline physical multiple industry states (convenience store, shopping mall, hypermarket, general merchandise store boutique supermarkets and convenience stores) and expands the online business (e-Vanguard, cross-border e-commerce) on this basis. Alibaba has arranged the offline fresh supermarket Freshhema, meets the diversified and experiential demands of consumers by shopping online and delivery offline.

At present, Chinese retail enterprises are still exploring the omni-channel business model. This paper focuses on the constituent elements of the omni-channel business model, analyzes the content of omni-channel business model innovation of retail enterprises and provides theoretical reference for retail enterprises to improve competitiveness through business model innovation.

\section{CONSTITUENT ELEMENTS OF BUSINESS MODEL}

2.1 Definition of business model

Scholars at home and abroad have given many views on the definition of the concept of business model. It is widely accepted that it is defined from the perspective of value creation [1]. A scholar proposed that the business model can be described and defined by nine basic elements such as Customer Segments, Value Propositions, Channels, Customer Relationships, Revenue Streams, Key Resources, Key Activities, Key Partnerships and Cost Structure [2].

Customer segments enables enterprises to divide customers into different groups according to their needs and behaviors and selects specific customer groups as target customers to reach and serve. Value propositions describes the bundle of products and services that enterprises use to solve customer problems, meet customer needs and create value for a specific Customer Segment. "Channels" describes how enterprises provide products and services to their customer segments to deliver value propositions. Customer relationship refers to the establishment and maintenance of specific customer relationships in each market segment. Revenue streams is the enterprise income obtained by delivering value proposition to the customer segment. Key resources are the human resources, financial resources, knowledge assets and other key factors required to make a business model work. Key activities describe the key business activities an enterprise must undertake to ensure the viability of a particular business model. Key partnerships describe the network of suppliers and partners that make the business model work effectively; Cost structure describes all costs incurred to operate a particular business model.

On the basis of his business model canvas theory, this paper will discuss the nine elements of the omni-channel business model of retail enterprises.

\subsection{Constituent elements of omni-channel business model of retail enterprises}

On the Background of increasing permeability of the internet and big data, the alternatives of ages and income stratum structure change the major retail consumers groups. Shopping behavior of consumers has the following characteristics: personalization, customization, sociality, and personal experiences. The rise of the omni-channel consumer group puts forward new requirements for retail enterprises. It has become a trend for retail enterprises to create an omni-channel business model with indiscriminately shopping choice.

Omni-channel retailers integrate the physical shops, online shops and 
other retail channels and combine the interactive features of information media (web sites, WeChat, email, social media, etc.) to meet the consumers' comprehensive experience demand of shopping, entertainment and social.

There are so many retails industry state, which correspond to different target customer groups. For instance, consumers are divided into online and offline customers according to different consumption channels.

One of the scholars thinks that business model describes how an enterprise creates value, delivers value and captures value. Omni-channel retail presents a customer-focused value proposition [3]. Driven by this value proposition, retail enterprises provide barrier-free and personalized experience to customers through multiple channels.

Omni-channel refers to the enterprises meet the consumer demand and Experiential demand at anytime and anywhere by coordinating integration of different channels. Compared to traditional off-line retail, breadth and the depth of Omni-channel all had the obvious expansion. Therefore, Consumers' behaviors such as election, purchase and payment are no longer limited to a same fixed channel but can occur in any channel.

Omni-channel retailers use the big data platform to collects and analyzes the data of trading history and future demand .Then they draw consumer mapping and identifies different consumers' personalized consumer preferences by analyzing data about customer basic attributes (name, gender, age, location, occupation, personal preferences), historical trading (POS data, online orders, purchase frequency, trading habits, category and brand preference) , shopping channels, social data. The retailers provide precision marketing and the personalized service to improve customer loyalty.

The core resources of the omni-channel model are financial resources and technical resources. On the one hand, the omni-channel transformation of retail enterprises expands the online and offline business scope. Under such circumstances, the network layout of physical stores, distribution centers, online channels and information integration requires capital support. On the other hand, the omni-channel business model of retail enterprises relies on big transaction data and big interactive data in all business links, therefore enterprises require ability of big data analysis, data perception and interaction.

Omni-channel activities includes five link, omni-channel flow, Omnichannel transformation, omni-channel trading, omni-channel delivery and omni-channel after-sales service. The key activities focused on omnichannel flow and omni-channel trading. Retailers integrate online and offline business through different channels. In addition, omni-channel businesses include data analysis, omni-channel storage, logistics network, category structure, experiential marketing and services. These businesses require support of commodity department, logistics department marketing department.

Based on a study, supply chain of omni-channel, its core is retailer cooperate with upstream and downstream firms as well as social media [4]. Therefore, there is a fast response network chain structure based on big data management.

Compared with traditional retail enterprises, the cost structure of omnichannel retail enterprises have changed greatly. The logistics cost, artificial cost and rent account for a fairly large proportion of traditional retail enterprise cost. In contrast, integrated operation management mode of omni-channel enterprises diminishes the logistics cost, transaction cost and production cost.

Based on the analysis of big data of category sales, the omni-channel logistics network optimizes category and quantity of inventory, and shares the whole channel inventory, which greatly reduces the delivery cost. Omni-channel retail achieves supply chain optimization, inventory minimization, category diversification and marketing precision and decreases the operation expenses such as staff salary, rent and power expenses.

\section{THE INNOVATION CONTENTS OF THE OMNI-CHANNEL BUSINESS MODEL OF RETAIL ENTERPRISES}

According to the nine elements of the omni-channel business model, the innovation contents mainly include industry state innovation, marketing innovation and technological innovation

The retail industry state is the different managerial formation formed by retail enterprises, which are providing the specified good and service to achieve different customer values and meet different consumption demands. Based on the analysis of customers and business district, the retail enterprises devise a new industry state combination for the specific customer group with different elements, including site selection, category structure, price policy, sales method, and VI design and service function [5]. There are different kinds of industry states in the retail enterprises at present, such as hypermarkets, warehouse store, convenience store, shopping mall, department store and specialty store. Then, the retail enterprises need to ensure the growth and innovation of the industry state with the upgrading of the market and customer. The core content of the industry state innovation is the customer value innovation and segmentation. According to research, the value proposition of the omnichannel business model is customer-centric [6]. To realize the goal of the personalized value of customers, the retail enterprises should optimize the existing industry states and device new industry states with the customer and industry state maps in the big data analysis platform for the diversification and integration of the retail industry states.

According to the customer maps in the big data analysis platform, the retail enterprises can deeply understand the customer needs and conduct precision marketing campaigns for the individual customer. The omnichannel marketing innovation in the retail enterprises includes marketing channel and marketing method. Because of the transformation between online and offline after adopting the omni-channel model, the marketing channel has been broadened. Combining with the economic and convenience of online marketing and the experience, entertain and sociality of offline marketing, the retail enterprises can provide more trading methods and interactive channels, such as online affiliate marketing and offline theme activity. The marketing innovation of the omni-channel business model in the retail enterprises is not only a good supplier, but also a life proposal supplier for the experiential marketing. The systematic marketing method can enhance the convenience, comfort and entertain of the consumer process. First, the method can increase the sensory, emotion and action experience of the customers by upgrading store image, optimizing VI logo and providing scene display; then, the method can attract target customers and stimulate consumption by enhancing the customer communication and user engagement of experience marketing.

The realization of the omni-channel retail model owes to the transformation of technology, which has changed consumer habits and improved operational efficiency. The technological innovation of the retail enterprises is mainly reflected in the big data technology and the terminal equipment, such as inventory, supply chain, POS store system, which can provide data to analyze commodity, business district and consumer for the optimization of the operational efficiency. With the development of the intelligence and entertain for the retail terminal, the innovation of the digital terminal has provided more methods to get product information and fun experience. For example, customers can confirm order information through the mobile terminal scan code and shopping basket identification; the customer face book coverage is broader through the life of mobile APP.

\section{CONCLUSIONS}

In this paper, the main conclusion includes two parts. First, we have defined the omni-channel business model from the nine basic elements, including Customer Segments, Value Propositions, Channels, Customer Relationships, Revenue Streams, Key Resources, Key Activities, Key Partnerships and Cost Structure. Second, with the analysis of the constituents, the innovation of the omni-channel business model includes industry state innovation, marketing innovation and technological innovation, which of the first two parts have created customer value and the last one has promote the former parts.

The retail enterprises should shift from retails to the online and offline integrated service provider to achieve the omni-channel supply and logistics integration, back-end support department sharing, and open online and offline transaction. To realize the innovation of the omnichannel business model, the retail enterprises should improve business insight by the big data and internet technology, segment consumer market, provide the richer "product + service" combination, develop the own 
brand and full coverage of life service, device more segmentation industry states, provide the consumers with cost-effective value services to get different kinds of profit models.

\section{ACKNOWLEDGMENTS}

The research of this thesis is supported by the foundation for the project "Research on the Business Model of Retail Enterprises under the Mode of Omni-channel" (Project Number: 2017KY003).

\section{REFERENCES}

[1] Xiang, G.P., Zhou, P.J. 2013. An Empirical Research on the Impact of Business Model on the Performance of Retailers from the Perspective of Customer Value Creation. Guangdong Business University Journal, 28 (1), 25-33.

[2] Osterwalder, A., Pigneur, Y. 2010. Business Model Generation -
A Handbook for Visionaries. Game Changers, and Challengers, Wiley, 06.

[3] Liu, Y., Liu, Y.Z., Tang, D.N. 2016. Research on Construction of OmniChannel Business Model of Retail Enterprises in Internet Era. Beijing Technology and Business University Journal, 31 (6), 34-42.

[4] Zhang, Z.J., Xue, C.L. 2016. Research on Optimization of the Retail Supply Chain in Omni-Channel Mode. Industry Economy Forum, 3 (4), 468-476.

[5] Yang, C.R., Zheng, S.R., Lu, Y. 2014. Research on Business Model Innovation of Retail Enterprises Driven by Big Data. Commercial Age, (27), 15-16.

[6] Peng, H.F., Huang, M.Y. 2014. Retail Business Model Innovation and Its Path Analysis in the New Technology Environment, Take Suning Cloud Commerce for Example. Macro-Economic Research, (2), 108-115. 